
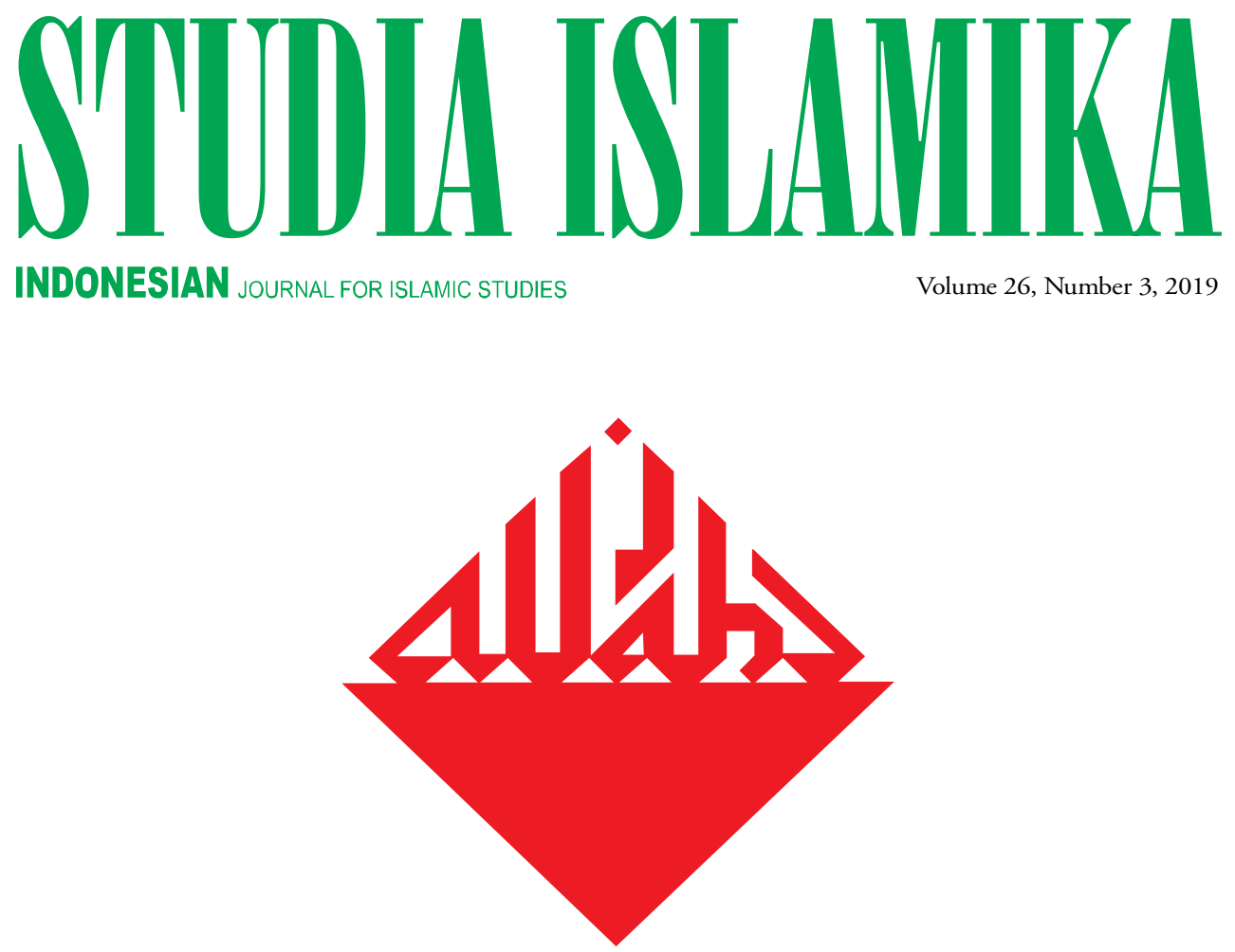

Pretext for Religious Violence in Indonesia: An Anthropolinguistic Analysis of Fatwas on Ahmadiyya Fariz Alnizar

Food and Local Social Harmony:

Pork, Communal Dining, and Muslim-Christian Relations in Flores, Indonesia Yohanes S. Lon \& Fransiska Widyawati

Religious Pluralism Revisited: Discursive Patterns of the Ulama Fatwa IN INDONESIA AND Malaysia Syafiq Hasyim

The Decline of Traditional Learning Methods in Changing Indonesia:

Trends of Bandongan-Kitäb Readings in Pesantrens Ervan Nurtawab 
STIUDLA ISLAMIIIKA 



\section{SIIIDIA ISLAMIIIKA}

Indonesian Journal for Islamic Studies

Vol. 26, no. 3, 2019

EDITOR-IN-CHIEF

Azyumardi Azra

MANAGING EDITOR

Oman Fathurahman

EDITORS

Saiful Mujani

Jambari

Didin Syafruddin

Jajat Burhanudin

Fuad Jabali

Ali Munhanif

Saiful Umam

Dadi Darmadi

Jajang Jahroni

Din Wahid

Euis Nurlaelawati

INTERNATIONAL EDITORIAL BOARD

M. Quraish Shihab (Syarif Hidayatullah State Islamic University of Jakarta, INDONESIA)

M.C. Ricklefs (Australian National University, AUSTRALIA)

Martin van Bruinessen (Utrecht University, NETHERLANDS)

John R. Bowen (Washington University, USA)

M. Kamal Hasan (International Islamic University, MALAYSIA)

Virginia M. Hooker (Australian National University, AUSTRALIA)

Edwin P. Wieringa (Universität zu Köln, GERMANY)

Robert W. Hefner (Boston University, USA)

Rémy Madinier (Centre national de la recherche scientifique (CNRS), FRANCE)

R. Michael Feener (National University of Singapore, SINGAPORE)

Michael F. Laffan (Princeton University, USA)

Minako Sakai (The University of New South Wales, AUSTRALIA)

Annabel Teh Gallop (The British Library, UK)

Syafaatun Almirzanah (Sunan Kalijaga State Islamic University of Yogyakarta, INDONESIA)

\section{ASSISTANT TO THE EDITORS}

Testriono

Muhammad Nida' Fadlan

Abdullah Maulani

ENGLISH LANGUAGE ADVISOR

Benjamin J. Freeman

Daniel Peterson

Batool Moussa

ARABIC LANGUAGE ADVISOR

Tb. Ade Asnawi

\section{COVER DESIGNER}

S. Prinka 
STUDIA ISLAMIKA (ISSN 0215-0492; E-ISSN: 2355-6145) is an international journal published by the Center for the Study of Islam and Society (PPIM) Syarif Hidayatullah State Islamic University of Jakarta, INDONESIA. It specializes in Indonesian Islamic studies in particular, and Southeast Asian Islamic studies in general, and is intended to communicate original researches and current issues on the subject. This journal warmly welcomes contributions from scholars of related disciplines. All submitted papers are subject to double-blind review process.

STUDIA ISLAMIKA has been accredited by The Ministry of Research, Technology, and Higher Education, Republic of Indonesia as an academic journal (Decree No. 32a/E/KPT/2017).

STUDIA ISLAMIKA has become a CrossRef Member since year 2014. Therefore, all articles published by STUDIA ISLAMIKA will have unique Digital Object Identifier (DOI) number.

STUDIA ISLAMIKA is indexed in Scopus since 30 May 2015.

Editorial Office:

STUDIA ISLAMIKA, Gedung Pusat Pengkajian

Islam dan Masyarakat (PPIM) UIN Jakarta,

Jl. Kertamukti No. 5, Pisangan Barat, Cirendeu,

Ciputat 15419, Jakarta, Indonesia.

Phone: (62-21) 7423543, 7499272, Fax: (62-21) 7408633;

E-mail: studia.islamika@uinjkt.ac.id

Website: http://journal.uinjkt.ac.id/index.php/studia-islamika

Annual subscription rates from outside Indonesia, institution: US\$ 75,00 and the cost of a single copy is US\$ 25,00; individual: US\$ 50,00 and the cost of a single copy is US\$ 20,00 . Rates do not include international postage and handling.

Please make all payment through bank transfer to: PPIM, Bank Mandiri KCP Tangerang Graha Karnos, Indonesia, account No. 101-00-0514550-1 (USD),

Swift Code: bmriidja

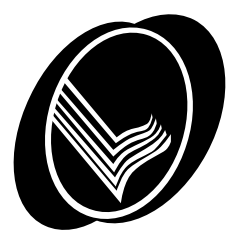

Harga berlangganan di Indonesia untuk satu tahun, lembaga: Rp. 150.000,-, harga satu edisi Rp. 50.000,-; individu: Rp. 100.000,-, harga satu edisi Rp. 40.000,-. Harga belum termasuk ongkos kirim.

Pembayaran melalui PPIM, Bank Mandiri KCP Tangerang Graha Karnos, No. Rek: 128-00-0105080-3 


\section{Table of Contents}

\section{Articles}

417 Fariz Alnizar

Pretext for Religious Violence in Indonesia:

An Anthropolinguistic Analysis

of Fatwas on Ahmadiyya

445 Yohanes S. Lon \& Fransiska Widyawati

Food and Local Social Harmony:

Pork, Communal Dining, and Muslim-Christian

Relations in Flores, Indonesia

475 Syafiq Hasyim

Religious Pluralism Revisited:

Discursive Patterns of the Ulama Fatwa

in Indonesia and Malaysia

511 Ervan Nurtawab

The Decline of Traditional Learning Methods

in Changing Indonesia:

Trends of Bandongan-Kitāb Readings in Pesantrens

543 Jamaluddin

Al-Shabakāt al-ijtimā‘̄ìyah wa al-fikrīyah

bayn muslimī Lombok wa Sumatera:

Dirāsah fī tuḥfah wa makhṭūṭ Sasak 


\section{Book Review}

585 Muhammad Nida' Fadlan

Lebih dari Sekedar Katalog Manuskrip:

Jejak Intelektualisme Islam di Mindanao

\section{Document}

603 Ismatu Ropi

Whither Religious Moderation?

The State and Management of

Religious Affairs in Contemporary Indonesia 
Fariz Alnizar

Pretext for Religious Violence in Indonesia: An Anthropolinguistic Analysis of Fatwas on Ahmadiyya

\begin{abstract}
This study uses an anthropolinguistic approach to examine two Majelis Ulama Indonesia (MUI) fatwa texts regarding Abmadiyya. First, it shows that there are significant differences between the 1980 and 2005 fatwas. Second, in terms of their lexicon, the 1980 fatwa uses the phrase "di luar Islam" (outside Islam), while the 2005 fatwa uses the phrase "berada di luar Islam" (located outside Islam). Third, there is an emphasis on the responsibilities of the government within the 2005 fatwa on Ahmadiyya. Fourth, the 1980 fatwa was directed at the Qadiyan Ahmadiyya, while the 2005 fatwa was directed at all elements of Ahmadiyya. Fifth, the form of the 2005 fatwa is reminiscent of a legal proclamation. This strongly affected the violence experienced by Ahmadiyya, as the fatwa was no longer presented as an opinion, but as a legally binding decision.
\end{abstract}

Keywords: Fatwa, Ahmadiyya, Anthropolinguistics, Majelis Ulama Indonesia. 
Abstrak: Artikel ini meneroka aspek-aspek antropologis terkait fatwa Majelis Ulama Indonesia (MUI) tentang Ahmadiyah. Hasil studi menunjukkan bahwa, pertama, terdapat perbedaan yang signifikan pada fatwa yang dikeluarkan pada tahun tahun 1980 dengan 2005. Perbedaannya terdapat padaaspek bentuk atau struktur fatwa. Kedua, dari sisi leksikon, jika pada fatwa MUI tentang jemaah Ahmadiyah tahun 1980 frasa yang digunakan adalah "di luar Islam", maka pada fatwa MUI tentang aliran Ahmadiyah tahun 2005 yang digunakan adalah frasa "berada di luar Islam". Ketiga, ada titik tekan tentang kewajiban pemerintah yang ditandai dengan kata-kata yang dicetak tebalpada Fatwa MUI tantang Aliran Ahmadiyah tahun 2005. Keempat, Fatwa MUI tentang Ahmadiyah tahun 1980 ditujukan untuk Ahmadiyah Qadiyan, namun pada tahun 2005 fatwa MUI tentang Ahmadiyah dimutlakkan. Kelima, bentuk fatwa MUI tahun 2005 yang menyerupai konsideran bukum memiliki korelasi kuat dengan tindak penyerangan sebab fatwa bukan lagi didukkan sebagai opini, namun lebih sebagai produk hukum yang mengikat.

Kata kunci: Fatwa, Ahmadiyah, Linguistik antropologis, Majelis Ulama Indonesia.

ملخص: يستشف هذا المقال الجوانب الأنثروبولوجية المتعلقة بنصوص الفتاوى

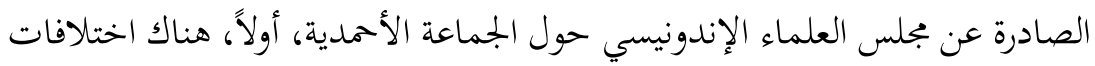

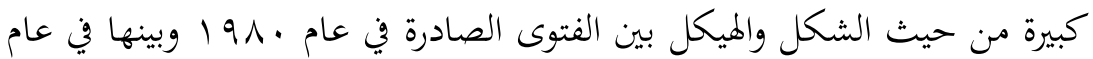

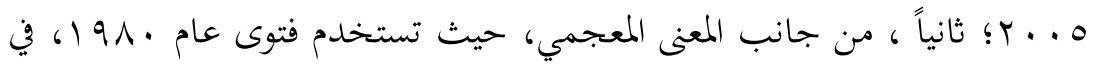

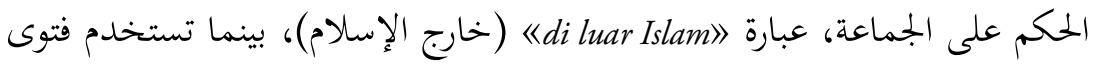

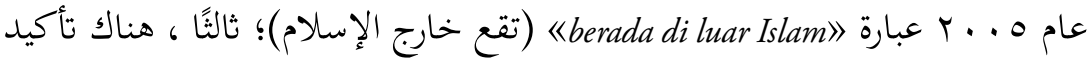

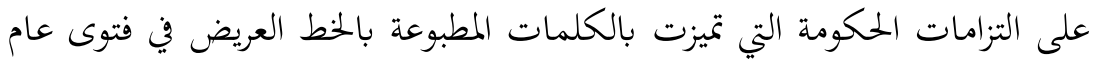

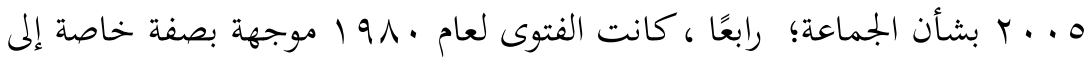

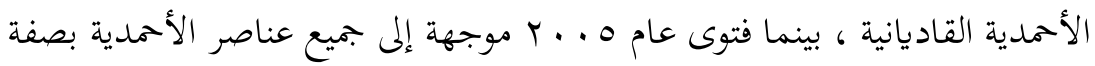

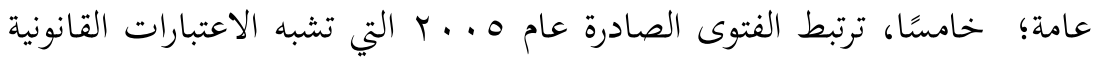

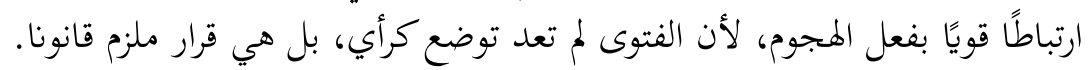
الكلمات المفتاحية: الفتوى، الأحمدية، اللسانيات الأنثروبولوجية، مجلس العلماء الإندونيسي. 
B isri (2010) wrote that the rapid increase in the number of fatwas in recent years is a new trend. The Majelis Ulama Indonesia (Indonesian Council of Ulamas, MUI) has issued 201 fatwas, covering topics such as religious behavior and beliefs, sharia economy, and halal products (Sholeh 2016, 115). This shows that the passion for passing fatwas, as argued by Bisri (2010), has reached a phase of 'latah'. Over time, these fatwas, which were expected to solve the problems faced by Indonesia's Muslims, have become subject to polemic and debate, and even used by some to justify violence (Hasyim 2016, 212). This tendency has prominently involved the fatwas on Islamic behavior. For example, according to a report by Madina Online, as of 2015, some 500 Ahmadis are living in refugee camps in Mataram, West Nusa Tenggara, with some having lived there since 2006 (Akibat Fatwa MUI, Ratusan Umat Islam Menderita di Transito 2015). As noted by Assyaukani $(2009,11)$, in 2002 there was an attack on an Ahmadi village in Maluku. That year, a number of places in Lombok were also attacked, including an Ahmadi mosque. In Kuningan, eighteen homes belonging to Ahmadis were destroyed (Assyaukanie 2009, 11).

Attack after attack occurred. In 2005, Ahmadiyya held a formal meeting at the Al-Mubarak in Bogor. Attended by 10,000 Ahmadis, this meeting was attacked by several groups. After this incident, MUI issued a fatwa on Ahmadiyya, its second such fatwa. In February 2006, another attack occurred, this time in the Bumi Asri housing complex in Ketapang Orong Hamlet, Gegerung Village, Lingsar District, West Lombok, West Nusa Tenggara. A number of residents drove the local Ahmadi population out of the complex, forcing them to live elsewhere (Pamungkas 2017, 3).

According to one report, this eviction was triggered in part by the 2005 MUI fatwa on Ahmadiyya. In this fatwa, it is explicitly stated that Ahmadiyya is a deviant and apostate sect. In one interview with Amanah magazine, as cited by Assyaukani (2009, 9), Habib Abdurrahman Assegaf-one leader of the attack on the Ahmadis in Bogor-said "gerakan kami, murni berdasarkan fatwa MUP" (our movement is based solely on the MUI fatwa).

Similar incidents - destruction, violence, evictions, and persecutionoccurred in other parts of Indonesia. For example, in Cikeusik, Ahmadis received discriminatory treatment from the local population. In Depok, West Java, conflict broke out between the local security forces and the 
Ahmadi population in June 2017. This was precipitated by the security forces confronting the Ahmadis, who were said to have re-opened a mosque that had been sealed by the State. Between 2011 and 2017, seven Ahmadiyya mosques have been forcibly closed (Penyegelan Masjid Ahmadiyah Depok - Infografik Tirto.id n.d.).

Misrawi notes that discrimination against Ahmadiyya has been diverse. This has included, for example, Ahmadis being prohibited from worshiping in mosques that they had built as a community. Elsewhere, Ahmadis have faced administrative discrimination, facing obstacles in obtaining legal documents and identification (Ahmadiyah Ada Sejak 1925, Setelah 2008 Diperlakukan Diskriminatif 2017).

President Soeharto gave two fundamental reasons for establishing the Indonesian Ulama Council (MUI). First, the government's desire to see religious people, particularly Muslims, unite. Secondly, the realisation that the many problems faced by the nation cannot be overcome without the active participation of scholars. Sholeh (2016, 70) argues that the establishment of the MUI was motivated by a collective awareness among Muslim leaders that a strong foundation is needed for an advanced and moral societal development process in Indonesia. In supporting this development process it is necessary to establish an organization as a place for scholars to express their aspirations and ideas. This view differs from Hooker's (2003, 60), who stated that the most dominant reason for the government establishing the Indonesian Ulama Council (MUI) was to control public religious expression. Assyaukani (2009) and Hasyim (2015) argue that there are political factors that underlie the establishment of the Indonesian Ulama Council (MUI); namely the ruling regime during that time was well aware of the important and strategic position of ulama in Indonesian society.

The forms of discrimination against the Ahmadiyya congregation are very diverse. They include the destruction of dwellings and making it difficult to worship in mosques that have been built together (Koerner and Putro 2017, 15; Suryana 2017, 85). In other places, administrative discrimination makes it difficult to create identity documents. There are at least eleven different kinds of intimidating behaviors and violence that affect the Ahmadiyya congregation. Eleven of these behaviors include: physical violence by the authorities and the government, physical threats by the government or apparatus, discrimination by 
the government, threats of violence from mass organizations, physical threats by the surrounding environment, threats through social media, verbal expressions of hate, expulsion and bullying (Fuller 2011, 5; Mariani 2013, 22-23; Tigor, Halili, and Sudarto 2017). Wilson (2018, 126) notes that neither the government nor the court did much to prevent these events.

Many adults perceive fatwas as equal to and the "same as" law, despite these documents being very different. Fatwas are not legal products, but opinions or views (Al-Zabidi 1965, 211). As such, obeisance is voluntary, not compulsory. Unlike fatwas, which are non-binding, laws are binding and obeying them is compulsory. This misunderstanding of fatwas has become increasingly problematic in the current context, in which the demand for fatwas is growing. As Bisri (2016) argues, the demand for fatwas has reached a point of excessiveness. This was also argued by Vice President Jusuf Kalla when speaking at the opening ceremony of the 2009 Fatwa Commission Meeting. He urged MUI to provide solutions, rather than issue fatwas that can create fear and unrest in society (Wapres Minta Fatwa MUI Tak Jadi Ketakutan Baru n.d.).

New problems and unrest have emerged because of the issuing of various fatwas regarding religious behavior. Where fatwas declaring certain religious beliefs as deviant and apostate are issued, conflict is certain to follow. Society becomes fragmented and polarized, divided into blocs supporting and opposing groups that are the subject of the fatwas. Whether or not it is recognized, fatwas declaring certain schools as deviant, or certain behaviors as apostate, leads to horizontal conflict within communities. As such, it is necessary to utilize proper and refined diction to avoid creating further horizontal conflict.

According to the researcher's records, between 1975 and 2017, MUI issued eight fatwas regarding Islamic behavior and beliefs. In 1980, two schools were declared deviant: Ahmadiyya and Islam Jama'ah. This was followed by a 1984 MUI fatwa regarding Shi'a. In 1994, MUI issued a fatwa regarding Darul Arqam; the same year, MUI issued another fatwa regarding Inkar Sunnah. Three years later, MUI declared Salamullah to be a deviant sect. In 2005, MUI again declared Ahmadiyya to be a deviant sect. Another fatwa was issued in 2011, this time elucidating the topic of Ahmadiyya. Most recently, in 2016, MUI issued a fatwa regarding Gafatar. 
Interestingly, of these eight fatwas regarding Islamic behavior and beliefs, three have dealt with Ahmadiyya: in 1980, 2005, and 2011. As stated by Assyaukani $(2009,12)$, the latter two fatwas are revisions of the earlier fatwa. The texts of these fatwas, which were issued in different years, are presented using different forms and characteristics.

Elucidation of the 2005 MUI fatwa on Ahmadiyya was issued some years later. In 2011, further elucidation was provided in an official fatwa issued by MUI. The texts of these fatwas regarding Ahmadiyya are interesting to study for several reasons. First, these fatwas are different in character from fatwas regarding other religious beliefs that are considered deviant, as evidenced by the fact that two fatwas have been issued by MUI, as well as several elucidations. Second, Ahmadis have experienced considerable harassment and violence. Third, there is a correlation between MUI fatwas and the violence experienced by Ahmadis (Assyaukanie 2009, 11; Hasyim 2015). In other words, the texts of these fatwas may be used as justification for violence, discrimination, and other activities. The texts of these fatwas have "power", a force and legitimacy; they are not persuasive, but tend to be understood as authoritative.

This study examines the MUI fatwas regarding Ahmadiyya from an anthropo-linguistic perspective. It offers a descriptive study, focusing on the anthropological aspects of the MUI fatwas regarding Ahmadiyya. In a detailed analysis, this study seeks to show the correlation between the persecution, violence, and harassment experienced by Ahmadis and the MUI fatwas regarding Ahmadiyya.

\section{Social Semiotics, Ideology, and Power}

Research into the connection between language and social semiotics is closely linked to research into the connection between language and culture, which is termed ethnolinguistics, or anthropolinguistics. Anthropolinguistics examines different linguistic forms and their relationship with culture (Halliday 1978, 86). Language is a social fact, one that cannot be separated from culture. According to Djajasudarma $(2009,30)$, the study of language is truly the study of cultural practice.

According to Foley (2001,3-5), anthropolinguistics seeks to reveal the hidden meaning underlying language and its use. Suhandano (2004, 33) clearly distinguishes between anthropolinguistics and linguistic anthropology. The main difference between these approaches lies in 
their point of departure; anthropolinguistics begins with linguistic fact, while linguistic anthropology begins with cultural fact.

Van Dijk (2000, 84-85) argues that there is always a connection between discourses (texts) in society and power. Within each social structure, there is always a practice of dominance, which is not natural but constructed. Van Dijk briefly describes the nature of power, including its creation and implementation. First, power is a device or structure produced through the relationships between social groups, institutions, and organizations. Second, social power is defined as the practice of control by one group over another. Third, the power of a certain group can be readily practiced and exerted in specific fields (e.g. economics, politics, media, and law). Fourth, dominance refers to the misuse of power through specific social practices. It is a widespread phenomenon. Fifth, a group's power is rooted in its access to privilege, and whoever has access to power has the potential to exert dominance. Sixth, social power and dominance are frequently organized and institutionalized. Seventh, dominance is rarely absolute, and may instead be gradual, implemented over time to ease the practice of power and hegemony.

These seven points are important to discuss, as they provide a basis for further discussion of hegemony, power, and its social practice. In social practice, there is always the question, or even accusation: who has the right to write about who, what, when, for whom, and in what context are hegemony and power practiced? There is also the question: who is permitted to participate in a communication event? Who has the power over everything? Such questions suggest two key concepts: discourse and access to the production of discourse.

Lukmana $(2003,330)$ states that dominance is understood as the application of social power by certain elites, institutions, and groups, resulting in social inequality based on political choice, race, gender, and ethnicity. Social power is rooted in access to resources with social value, such as wealth, income, positions, offices, and discursive practices. Such power not only determines one's control of actions, but also their control of cognition. As such, the practice of power is not purely physical; it is also exerted over human thought. This is reminiscent of Smith's statement (2012) that colonialism and imperialism in the 20th century is not limited solely to military and economic power; rather, they have become analytical and discursive, exerted through science and knowledge. Colonialism has shifted from "structure" to "culture", 
but the power exerted remains hegemonic. It is nothing other than cultural invasion. Of course, such practice of power is more cognitive than physical. Various forms of power seek to control our cognition. When we attempt to change the color of our skin, make our fashion choices, or even clean our genitals, we are being influenced by such "power".

\section{Fatwa and the Majelis Ulama Indonesia}

Before discussing the Majelis Ulama Indonesia as the institution that issues fatwas, the researcher will present a definition of fatwa. This definition will include the tendencies of fatwas in early Islam. The definition, concept, and history of fatwas will provide the necessary context for discussing the institution that issues fatwas in Indonesia (i.e. MUI).

Jum'ah $(2008,5)$ writes that fatwas are specific decisions made by muftis (persons tasked with issuing fatwas) in response to and in addressing specific topics. Al-Zabidi $(1965,774)$ defines fatwas as "Islamic legal opinion[s] issued by a Muslim jurist". A broader definition is provided by Sholeh $(2016,12)$, who understands fatwas as responses, decisions, or opinions issued by muftis, fatwa institutions, and fatwa commissions regarding religious issues. From this definition, it appears that the definition of fatwas has been contextualized for settings such as Indonesia, where fatwas are issued not by individual muftis but by specific organizations. Moreover, Al-Jauzi $(2007,10)$ positions fatwas as interpretations and opinions; as such, muftis are best understood in this context as 'interpreters'.

From these definitions, there is a clear uniting theme: fatwas are opinions issued by individuals (muftì). This definition centers on the fact that fatwas are produced and issued to answer specific questions. In other words, fatwas are responses to questions asked of muftis or organizations given the authority to issue them, such as MUI in Indonesia. Interestingly, in this context, is Qarrafi's view that muftis are quite similar to interpreters. Implicitly, as interpretations, the decisions made by muftis are relative. As they are interpretations, they need not be obeyed or observed.

Fatwas first began to be issued during the life of the Prophet Muhammad. At the time, the Prophet was frequently consulted when followers faced new problems. The opinions of the Prophet were the 
fatwas of the time. After the death of the Prophet, the authority for granting fatwas was delegated to the caliphs who succeeded Him: Abū Bakr, 'Umar ibn Khațtāb, Uthmān ibn 'Affān, and 'Alī ibn Abī Ṭālib. According to Hallaq (1984), during the Umayyad Caliphate (around the mid-17th century), muftis occupied important positions in society and were paid handsomely by the government. They were frequently given the title Shaykh al-Isläm, or Grand Mufti. This practice was adapted by other Muslim-majority countries following the collapse of the Ottoman Empire. In Egypt, for example, muftis were given the title Grand Mufti, while in Saudi Arabia they became known as mufti mamlakah (Muftīs of the Kingdom). Countries such as Morocco, Tunisia, and Jordan also have Grand Muftis (Assyaukanie 2009, 4).

Indonesia appears to be one of few Muslim countries that have not followed the traditions of the Umayyad Caliphate. Indonesia has never had a Grand Mufti or Shaykh al-Isläm, but rather it has institutionalized its fatwas. In other words, authority for issuing fatwas is vested not in individuals, but rather in the collective known as Majelis Ulama Indonesia (MUI), which was established on 26 July 1975 in Jakarta. Five years before MUI was founded, several meetings of ulamas and Muslim leaders were held. Between 30 September and 4 October 1970, for example, a conference was held at the Pusat Dakwah Islam (Center for Islamic Communications), involving a broad range of ulamas, intellectuals, and scholars. During this conference, Ibrahim Hosen presented a paper inspired by the 1964 decision of the Majma' Buhust Islamiyyah (Center for Islamic Studies) at Al-Azhar University, Cairo regarding the importance of collective ijtihäd (exertion of mental faculties in finding a solution to a question). This view was challenged by the charismatic and productive ulama Haji Abdul Malik Karim Amrullah, best known as Buya Hamka, who argued that collective ijtihäd would enable the involvement of secular scholars. As an alternative, Hamka suggested that a Grand Mufti be chosen to provide input and advice to the Indonesian government. The ensuing debate was unresolved, and participants did not reach agreement (Assyaukanie 2009, 4-5; Hamdi 2007, 88; Sholeh 2016, 70-71).

Another conference of Indonesian ulamas and Islamic scholars was held four years later at the same location in the Pusat Dakwah Islam in Jakarta. Unlike the first conference, the meeting reached a decision, urging the establishment of an agency consisting of ulamas who resided 
throughout the country, with branches at various administrative levels. President Soeharto played an important and direct role in this agency. The ultimate realization of this decision was the formal establishment of the MUI on 26 July 1975 at the peak of a conference held between 21 and 27 July. This conference was subsequently claimed to be MUI's first Musyawarah Nasional (national conference, Munas). At this time, Buya Hamka — who had initially been a staunch opponent of such an agency being established-was chosen to be its chair. This is not to say that Hamka had no reason to accept this position; rather, he had at least two. First, he considered it necessary for Muslims to work together with the Soeharto government. Second, he believed that MUI would serve to strengthen the ties between the Indonesian government and the country's Muslim population (Hosen 2004, 80; Sholeh 2016, 70).

As for the Soeharto government, it provided two main reasons for establishing the Majelis Ulama Indonesia (MUI). First, the Soeharto government sought to ensure that all of Indonesia's religious communities stood united. Second, the government recognized that many of the nation's problems could not be overcome without the active participation of the ulamas. Sholeh $(2016,70)$ argues that MUI's establishment was ultimately rooted in Muslim leaders' recognition that Indonesia required a strong foundation for building a prosperous and moral society. They considered it necessary to establish an organization that could represent the ulamas' aspirations and ideas as part of the national development process.

According to Assyaukani (2009) and Hasyim (2015), political factors influenced MUI's establishment. The regime was aware of the important and strategic position that ulamas played in Indonesian society.

"... the agency is closer to those in power than the people. After a lengthy process, Soeharto successfully convinced the ulamas-particularly the modernist ulamas-to establish MUI. Owing to this historical background, MUI has tended to side with the government rather than the faithful" (Hasyim 2015, 245)

This statement argues that MUI was established as an extension of the ruling regime, and indeed the political interests of the Soeharto regime are clearly present in the guidelines given in the president's speech. At the opening ceremony, Soeharto emphasized the importance of translating activities as a form of national development and 
mobilization, and mediating interactions between the government (as zu'amä' umarā), ulamas, and Islamic scholars (Hamdi 2007, 60). This indicates that a political purpose underlies MUI's establishment; namely, to neutralize the threat of political Islam. This was important within the contemporary political context, given the opposition exhibited by Indonesian Muslims under the Old Order government (Hamdi 2007, 68).

Sobary $(2010,248)$ identifies two types of Islam being practiced under Sukarno's Old Order government: shar'i Islam and tarekat Islam (i.e. tasawwuf). Shar'ī Muslims supported the government, as evidenced by the adage "enam puluh tahun dalam pemerintahan penguasa yang bobrok masih lebih baik dari pada anarki semalam" (sixty years of failed government is better than one night of anarchy), or in Arabic "sittūna sanatan min imāmin fäjirin așlahu min laylatin bilā sulțān". Furthermore, tarekat Muslims were opposed to the government, which they perceived as deviating from the formal truth of religion and thus deserving of open rebellion. This threat to those in power served as an important motivation for the Soeharto regime's establishment of a special agency for Muslims, in order to mitigate such risks.

Hooker (1997, 16) analyzed MUI's function between 1975 and 1990, arguing that it frequently supported and even justified government programs and policies. Following Hooker's argument, Mudzhar (1993, 58-60) contends that MUI was unable to resist the pressure placed on it by the government throughout the 1980s, and thus served to legitimize almost all government policies. One exception was a fatwa issued by Hamka, serving as MUI's chair, which prohibited Muslims from attending Christmas celebrations. This fatwa did not reflect government policies; indeed, President Soeharto often attended Christmas celebrations. Debate and polemics over this issue became increasingly heated, and ultimately Hamka formally resigned as the organization's leader, unwilling to rescind this fatwa (Hasyim 2015, 246).

According to Assyaukani $(2009,5)$, since its establishment MUI has had fluctuating membership. In the early years of the organization (1975-1981), only seven ulamas held positions within MUI. This changed over time; for example, in 2008, MUI consisted of 140 members. This was influenced by the Soeharto's resignation, after which the recruitment process became more open and democratic. 
As such, MUI members no longer come from a specific set of Islamic organizations, but also have backgrounds in academia, journalism, activism, or even politics. However, it should be noted that fluctuation in the organization's membership has not influenced its leadership patterns. Only two organizations have had cadres occupy MUI's highest office: Nahdlatul Ulama and Muhammadiyah. These are the largest and most influential in Indonesia. In order of tenure, MUI's leaders have been: Buya Hamka (1975-1981), KH. Syukri Ghozali (1981-1985), KH. Hasan Basri (1985-1998), KH. Muhammad Ali Yafie (19982000), KH. MA Sahal Mahfudh (2000-2014), Prof. KH. Sirajuddin Syamsuddin (act. 2014-2015), and KH. Ma'ruf Amin (2015-2020).

According to Sholeh (2016, 71-73), in MUI's early years, the organization functioned primarily to provide input and advice to Indonesia's government and Muslim population regarding contemporary religious problems and issues. MUI served to mediate between the ulamas, government, and the Muslim population. The relationship between MUI and the government in these early years was stable, with little tension. No fatwas issued by MUI in these six years were truly opposed to government policies. This changed in March 1981, when MUI issued a fatwa that forbade Muslims from attending Christmas celebrations. This fatwa led to tension between MUI and the government, which viewed this fatwa as having a negative effect on governance (Assyaukani 2009, 6).

Because of this tension, as well as Hamka's staunch refusal to rescind the fatwa, he ultimately chose to resign from his position as MUI's chair in 1981. KH. M Syukri Ghazali was named as his replacement. Under Ghazali, MUI implemented several programs, including revising the organization's constitution. MUI also issued fatwas regarding issues such as abortion, vasectomies, salpingectomies, the environment, and the population (Majelis Ulama Indonesia 2005a, 27).

Under the leadership of KH. Hasan Basri (1985-2000), MUI functioned primarily as a supervisory body, ensuring that national law did not run contrary to Islamic doctrine. Guiding the faithful in national life also appears to have been prioritized by MUI under his leadership. Furthermore, under Basri, the scope of MUI was expanded, as indicated by the establishment of the Lembaga Pengkajian Pangan, Obat-obatan, dan Kosmetika (Agency for the Consideration of Food, Medicine, and Cosmetics, or LP-POM), which was given the mandate 
of providing halal certification for domestic and imported foods, medicines, and cosmetics (Sholeh 2016, 73).

$\mathrm{KH}$. Hasan Basri died in 1998, and the ulamas chose KH. Ali Yafie as his replacement. The new leader implemented a variety of new policies and organizational reforms. These included a number of fatwas on social and religious issues. The most phenomenal of these was the prohibition of the Sumbangan Dana Sosial Berhadiah (Prizes for Social Financial Contributions, SDSB), which is considered a form of gambling disguised as charity. SDSB was a program organized and sponsored by the Yayasan Dana Bhakti Kesejahteraan Sosial (Charitable Foundation for Social Welfare, YDBKS). Afterwards, tensions emerged between KH. Ali Yafie (then Deputy Rais Aam at the Nahdlatul Ulama) and Abdurrahman Wahid, or Gus Dur (the chairman of Nahdlatul Ulama's Executive Body, which nota bene received aid from YDBKS). Subsequently, in 2000, KH. Ali Yafie resigned after only two years leading MUI. This position was then taken by KH. MA Sahal Mahfudh, the leader of the Maslakul Huda pesantren (Islamic boarding school) in Kajen, Pati. As a result, MUI was heavily criticized by young members of Nahdlatul Ulama, especially after the organization issued fatwas prohibiting liberalism, pluralism, and secularism in July 2005. KH. MA Sahal Mahfudh died in 2014, and in his place KH. Sirojuddin Syamsuddin was made the acting MUI chair. Also known as Din Syamsuddin, KH. Sirojuddin Syamsuddin was the Executive Director of Muhammadiyah from 2010 to 2015 and was frequently invited to speak at international forums. Afterwards, KH. Ma'ruf Amin - the Rais Aam of Nahdlatul Ulama-was chosen to lead the organization. He had previously served as member and as leader of MUI's fatwa commission from 2000 to 2007 (Assyaukanie 2009, 13; Sholeh 2016, 73-74).

Aside from identifying attempts to gain dominance and power made by Indonesia's two largest religious organizations, Nahdlatul Ulama and Muhammadiyah, Sholeh (2016: 75) made two claims. First, no MUI leader has received a university education. Second, MUI's leaders have received honoris causa doctorates from various universities. These claims, however, are incorrect, for Sirojuddin Syamsuddin had studied at university. Furthermore, not all of the organization's leaders received honorary degrees, as shown by KH. Syukri Ghazali, KH. Sirojuddin Syamsuddin, and KH. Hasan Basri. 
Institutionally, MUI consists of several commissions, including the Fatwa Commission, the Ukhuwah Islamiyah Commission, the Proselytization and Social Development Commission, the Islamic Education and Cultural Guidance Commission, the Research and Worship Commission, the Law and Legislation Commission, the Economic Empowerment Commission, the Commission for Empowering Women, Children, and Families, the Commission for Informatics and Mass Media, the Commission for Interfaith Harmony, and the Commission for International Relations (Majelis Ulama Indonesia 2005b).

The MUI fatwas may be characterized in two ways. First, they may be categorized based on their themes. Second, they may be categorized based on the forums that produced and issued them. Following the first categorization, the MUI fatwas cover several themes: sharia economics, halal products, and religious affairs. Fatwas regarding religious behavior and beliefs may be further divided by sub-theme: religious behavior and schools, worship, society and culture, and science and technology. Furthermore, following the second categorization scheme, MUI fatwas may be divided into four categories: those issued by the Fatwa Commission, those issued by the Dewan Syariah Nasional (National Sharia Council, DSN), Munas MUI, and the All-Indonesia Meeting of Ulama and Fatwa Commissions (Sholeh 2016, 84).

The following table categorizes MUI fatwas by theme. The data below has been collected from the anthology of MUI Fatwas, 19752015:

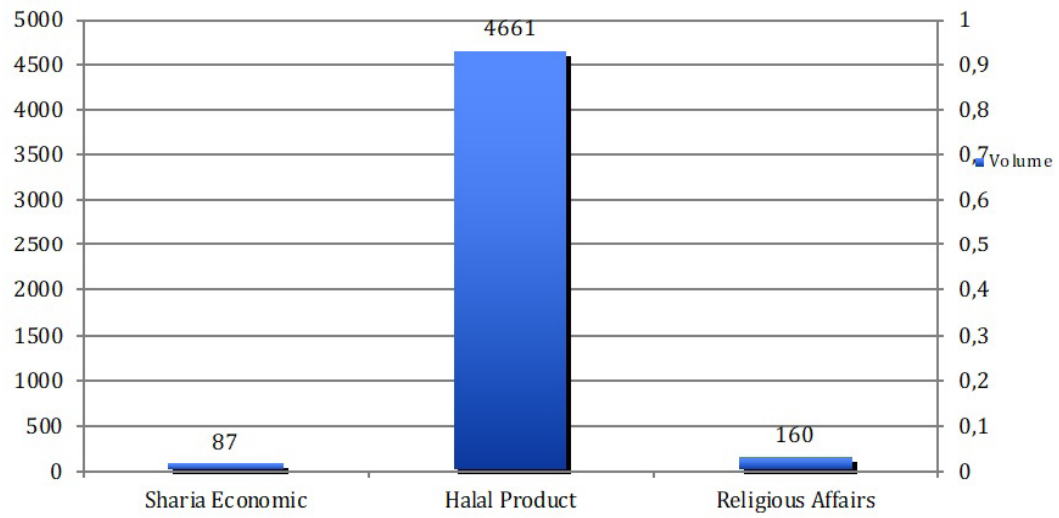

Diagram 1. Classification of MUI Fatwa by Topic

As the diagram above indicates, based on their classification, MUI fatwas can be divided into three major themes, namely Islamic 
economics, halal products, and religious issues. Each of the above themes consist of several sub-themes. Firstly, the theme of sharia economics includes fatwas about sharia banking, sharia insurance, sharia pawnshops, Islamic finance, sharia guarantees, sharia accounting, MLM (Multi Level marketing) Sharia, and sharia commodities. Fatwas with the theme of sharia economy amount to 87 fatwas. Second, fatwas related to halal products have two sub-themes, namely standardization of halal and the stipulation of halal products. Fatwas with the theme of halal products are considerably large, amounting to 4661 fatwas. Third, fatwas with the theme of socio-religious problems, under which there are four sub-themes: religious faith, worship, socio-cultural, and technological science. Fatwas with this theme that have been issued by the Indonesian Ulama Council amount to as many as 160 .

As shown in Diagram 1, fatwas determining the halal status for food, medicine, and cosmetics are the most common. The second most common are fatwas regarding religious issues, 160 of which have been issued. Of these religious issues, the most common sub-themes have been (in order) society and culture, science and technology, worship, and religious behavior and beliefs.

The above table explicitly contradicts the analysis presented by Nadjib in his discussion of the 2005 MUI fatwa regarding the prohibition of pluralism, radicalism, and fundamentalism. According to Nadjib, one must refer to the epistemology and linguistic philosophy of MUI itself, rather than the ulamas who operate within it. Currently, MUI's members are ulamas with expertise in the subject of fiqh (Islamic jurisprudence). Their knowledge is primarily religious and shari'a, despite the fact that, from its etymology, the word "ulama" itself is derived from the Arabic 'alima-ya lamu-ilman, which means, "to know" and thus refers to a knowledgeable person. Nadjib further argues that, as the spectrum of knowledge is quite broad, the concept of ulama may include experts on the subjects of biology, physics, mathematics, and so on, as well as experts on religious education and Islamic jurisprudence. From a philosophy of language perspective, the word ulama may be defined simply as a person with expertise in a certain field, with the ability to find God's greatness in every activity. An ulama in biology, for example, would find God's greatness in the science of biology, while an ulama in physics would find God's greatness in the atom, and so on (Cak Nun: Fatwa MUI Tak Mengikat n.d.). 
Nadjib's contention may have been heavily influenced by Bisri (2010, 39-43), who argued that misunderstandings of the term ulama are caused by linguistic difficulties. As Bisri writes:

"People's understanding of the ulamas has been negatively influenced, perhaps, first because of difficulty understanding ulama as a word and as a term, and because of different interpretations of the term ulama itself. No less important is the phenomenon of "ulama-ness" that has emerged as a result of such misunderstandings".

Bisri $(2010,43)$ further emphasizes that misunderstandings of the term "ulama" have emerged in a social context where the title may be granted to anybody. This occurred because different communities and groups have their own selection criteria for ulamas. This argument, however, collapses when we consider the number of fatwas dealing with science and technology: fifty in total, larger than the number of fatwas dealing with social and cultural issues. As such, it may be assumed that MUI also includes experts in the sciences. This is quite possible, keeping in mind that membership became increasingly open to people of diverse backgrounds following the fall of the New Order (Assyaukani 2009, 11).

In order to discuss the classification of MUI fatwas based on the forum in which they were issued, it is necessary to first consider the different categories. Sholeh $(2016,108)$ categorized four forums that are used to decide on a fatwa. First, the fatwa commission. This commission is a permanent organ owned by the Indonesian Ulama Council. Its members consist of members of the commission who are given official decrees by the Indonesian Ulama Council and are chaired by a chairman and commission secretary. The fatwa commission conducts regular meetings to discuss socio-religious issues. Meetings held by the fatwa commission are conducted once a week. The participants involved are commission members. Second, the National Sharia Council of the Indonesian Ulama Council (DSN-MUI). This institution is an autonomous organ under the auspices of the Indonesian Ulama Council (MUI). Coverage of topics discussed include economic and financial issues. As with the fatwa commission, meetings by the MUI DSN are held once a week. Third, the forum for the Ulama of the Fatwa Commission in Indonesia. This forum is temporary (ad hoc) and not included in the official structure of the Indonesian Ulama Council. Issues addressed by this forum include religious understanding, worship 
issues, social and religious issues, drug and food issues, and technological science. The forum consists of members of the fatwa commission of the central Indonesian clerical council, the head of the provincial-level fatwa MUI commission, the leadership of the fatwa organizations at the central level, the pesantren leaders, and Islamic universities. This forum is more strategic and is carried out at least once every three years. Fourth, the National Conference. This forum is temporary (ad hoc) and is part of the deliberation mechanism owned by the Indonesian Ulama Council (MUI). The range of topics discussed include issues of religious understanding, issues of worship, society, medicine and food, and science and technology.

The highest forum for the issuance of a fatwa is the National Conference, which is held every five years, after the ijtimác 'ulam $\vec{a}$. Following that, the MUI fatwa commissions and the MUI DSN have equal legitimacy. This legitimacy is obtained from the diverse number of participants who take part in the forum. The highest forum that can issue fatwas is the Munas, which is held once every five years. Following the Munas is the All-Indonesia Meeting of Ulama and Fatwa Commissions, then the various fatwa commissions and DSN-MUI (with equal legitimacy). A forum's legitimacy is based on its members.

Furthermore, according to MUI's official website, the organization was established at a time when the Indonesian people were experiencing a rebirth after thirty years of independence, with much energy being dedicated to specific groups' political interests rather than the welfare of the faithful. At this time, the ulamas of Indonesia wholly realized that they needed to continue the mission of the Prophet (warathat alanbiy $\bar{a})$. As such, they felt it was their calling to help develop Indonesian society through MUI, as the ulamas had done during the colonial era and during Indonesia's struggle for independence. On the other hand, they felt that Muslims were facing increasingly challenging global issues. As the cultural figure Imron stated, this included modernization in the fields of science and technology, which posed a considerable threat to the morals and local wisdom of the Indonesian people, as well as the rise of consumerism and hedonism, which were perceived as eroding the religious foundation upon which the Indonesian lifestyle was built (Imron 2012). It was thus believed that Muslims could descend into a state of extreme tribalism (ta'așsubiyah). As such, the ulamas considered it necessary for them to establish MUI as a means for Muslim leaders 
to work collectively and collegially to realize harmonious relationships, unity, and solidarity among Muslims (Sejarah MUI n.d.).

Over the first 25 years of its existence, MUI-as an organization facilitating discussions between ulamas, zu'amā, and Muslim scholarsprovided guidance to Muslims and sought to ensure society was blessed by Allah. MUI was also expected to provide the Indonesian government and society with fatwas and recommendations regarding social and religious issues, promote activities that included the faithful, ensure people remained religious in national unity, connect the ulamas with the government, and mediate between the faithful and government while promoting national development. The organization also intends to promote cooperation between Islamic organizations, institutions, and scholars by providing guidance and information to Indonesian Muslims.

Based on this discussion, it is clear that the embryo for MUI consisted of two different factors: internal factors and external factors. Internal factors include, for example, the need to legitimize and legalize the products of the Sukarno regime as well as the need to manifest Islamic brotherhood, with MUI acting as a mediator. External factors include the threat of global culture, which was perceived as being detrimental to Indonesia's local culture, as passed from generation to generation.

In recent years, MUI has been heavily criticized by people who feel that its fatwas are shallow, and that the organization promotes its own interests and often acts politically (Assyaukani 2009, 11; Hasyim $2015,10)$. Indeed, rather than receiving sympathy and support for its decisions, MUI has frequently been criticized, with its decisions being derided as ridiculous. Such criticism has been made, for example, by Ulil Abshar Abdalla and a number of human rights activists.

This research focuses on the texts of two fatwas issued by MUI regarding Ahmadiyya. Each fatwa was issued together with an elucidation. The first fatwa was issued in May 1980, with an elucidation following in 1984. A second MUI fatwa regarding Ahmadiyya was issued in July 2005, followed some time later by a lengthy elucidation.

\section{Fatwa on Ahmadiyya: Text and Context}

The first focus of this discussion is the form or structure of the texts of the MUI fatwas regarding Ahmadiyya. As aforementioned, MUI has issued two fatwas regarding Ahmadiyya in 1980 and in 2005. 
Furthermore, in 2011 a lengthy elucidation was issued, further dealing with Ahmadiyya.

The form of these texts illustrates several important points. First, the texts of the 1980 fatwa and the 2005 fatwa regarding Ahmadiyya have significant differences, despite these fatwas being related. In other words, the 2005 MUI fatwa regarding Ahmadiyya is a revision of the 1980 fatwa. Whereas the 1980 fatwa is relatively simple and direct, the structure of the 2005 fatwa is more complex, and includes a number of reasons for it being issued. Some of these reasons are sociological in nature, as indicated by the phrase 'menimbulkan keresahan masyarakat' (cause unrest in society). Other reasons are rooted in theological considerations, as well as the Quran and the Hadiths. Also referenced is a similar fatwa issued by the Organization of Islamic Cooperation.

Secondly, on the fatwa about the Ahmadiyya flow of 1980, there is an exclamatory element that proclaims: calls on MUI area level I and level II, scholars and dai to socialize the error of Ahmadiyya pilgrims, call for those who have already entered the Ahmadiyya congregation to immediately return to the true path of Islam, and the call to all Muslims to raise their vigilance so as not to be influenced by the Ahmadiyya. In the MUI fatwa concerning the Ahmadiyya flow issued in 2005, there is no such dictum specifically. It is only present in the fatwa decision, which also contains the phrase "for those who have followed the flow of Ahmadiyya to immediately return to the teachings of Islam that haq (rujū' ilá al-haqq) in line with the Quran and Hadith". This sentence is exactly the same as that contained in the MUI fatwa about Ahamadiyya pilgrims in 1980, but there is an additional explanation of the phrase 'returning to the right path by bearing the rujü' ilá al-haqq sentence' corresponding to the Quran and Hadith.

Third, in relation to the prohibition of the activities of the Ahmadiyya congregation, there are differences between the two fatwas. In 1980, the MUI emphasized that in relation to the issue of the Ahmadiyya congregation, the MUI must always be in contact with the government. This text did not exist in the fatwa issued in 2005. In fact, there is a sentence that reads: "The government is obliged to prohibit the spread of Ahmadiyah ideas throughout Indonesia and dissolve the organization and close all its activities".

In the first difference, there is a change in form from a simple to a more complex direction. This is a demand for the needs of the times. If 
the text of the 1980 MUI fatwa concerning the Ahmadiyya congregation was not compiled as it was appropriate for the dictum of a decision containing the element of consideration to weigh, then this does not apply to the 2005 MUI fatwa concerning Ahmadiyya sect. This is due to several factors. First, there is a demand to include theological footing that comes from the primary teachings of Islam (Quran and Hadith). Secondly, the MUI needs to refer to a similar decision by an organization that has international standing and stronger position and power, namely the Organization of Islamic Countries (OIC) decision issued in 1985. At this point it can be said that the text of the 1980 MUI fatwa did not refer to the OIC fatwa on the Ahmadiyya sect because when the MUI fatwa was issued, the OIC had not issued a fatwa on Ahmadiyah. However, it can also be interpreted that the MUI felt the need to refer to the stronger fatwas issued by international organizations on Ahmadiyya, meaning that at this point, it is very possible that the MUI could be considered less confident about the fatwa it decides if without including a similar fatwa issued by more global and international organizations. As Kaptein (1995, 144) argues, the tradition of referring to international decisions like this, especially to Muslim countries in the Middle East, has long been carried out by previous scholars. ${ }^{1}$

It is interesting to note that before 1980, the international Islamic world has issued a number of fatwas on Ahmadiyya. One of them, for example, was issued in 1974 by Rabitah Aalam Al-Islami (RAI), also known as the Moslem World League (MWL), at a conference held in Mecca. This was the first international fatwa issued about the Ahmadiyya sect. In 1978, the Organization of Islamic Countries (OIC) also issued a similar fatwa that banned the Ahmadiyya sect. In the fatwa issued in 1974, there were representatives from Indonesia who signed the dictum of the fatwa, namely HM. Rasjidi (Darmadi 2016, 28-29). Nevertheless, the 1980 fatwa of the MUI did not mention or refer to two fatwas issued by the two international fatwa organizations. The reason for the absence of such international fatwa references in the dictum of the 1980 MUI fatwa is indisputable. Before the fatwa concerning the Ahamdiyah sect of 1985 was issued by the OIC, and was referred to and affirmed by MUI in the 2005 fatwa, the international fatwa organization Rabitah Aalam Al-Islami (RAI), also known as the Muslim World League (MWL), issued fatwasin 1974 and 1978 on the Ahmadiyya sect. 
The second difference concerns the instructions from the board to the MUI level I and level II, Ulama and dai, to socialize the heretical segments of the Ahmadiyya congregation. This includes calls to those who have entered the Ahmadiyya congregation in order to immediately return to the right path of Islam, and a call to all Muslims to enhance their vigilance so as not to be influenced by Ahmadiyya ideas. In this context it is very clear that the 1980 MUI fatwa concerning the Ahmadiyya congregation was trying to expand the power of the fatwa to all its members, even the lowest layers of the MUI structure (at the regional level II) or district /city. On the contrary this did not occur in the fatwa issued by the MUI on the Ahmadiyya Flow in 2005. This was possible because the socialization of the fatwa had been deemed evenly distributed so that there was no need for socialization to the first and second levels, or by the ulama. What is interesting is the orders to Muslims to enhance their awareness of the Ahmadiyya sect. This aspect was not present in the 2005 MUI fatwa on the Ahmadiyya sect. The omission of the appeal aspect was very likely caused by the various demands on the MUI, which seemed to characterize Ahmadiyya as a dangerous organization, to encourage people to increase their vigilance. The position of MUI, which includes a call to the public to increase vigilance, attracted a lot of criticism and was considered too excessive. This is because the call positions the sect as a dangerous organization, even though the positioning is not entirely correct. Sociological accusations found in the dictum of the fatwa, which states "danger to the unity and unity of the state" are accusations that are very tendentious and tend to be unilateral.

This aforementioned condition ultimately triggers the emergence of the third dictum of the 2005 MUI fatwa item on Ahmadiyah, which states that the government is obliged to prohibit the spread of Ahmadiyya ideology throughout Indonesia and force organizations to close all places of activity. This attitude is actually more advanced and assertive when compared to the dictum of the 1980 MUI fatwa on the Ahmadiyya congregation. The 2005 MUI asks the government to do three things at once (1) prohibit the spread of Ahmadiyya's ideology (2) dissolve the organization, and (3) close all activities. The three forms of action mentioned are not included in the 1980 MUI fatwa concerning the Ahmadiyya congregation.

In terms of the lexicon, particularly in describing the position of the Ahmadiyya vis-a-vis Islam, there are interesting differences to be noted. 
First, the term used to describe the position of the Ahmadiyya. The 1980 fatwa of the Indonesian Ulama Council on Ahmadiyah reads: "In accordance with the data and facts found in 9 (nine) books on Abmadiyya, the Indonesian Ulama Council states that Ahmadiyah are worshipers outside Islam, misguided and misleading". In contrast, the 2005 fatwa reads "Reaffirming the fatwa of the MUI in National Conference II of 1980 which stipulates that Ahmadiyya is a sect that exists outside of Islam, misguided and misleading, and Muslims who follow it are apostates (out of Islam)." The 1980 fatwa uses the phrase "outside Islam", whereas the 2005 fatwa uses the phrase: "exists in the outside of Islam". In the 2005 fatwa, the notion that the Ahmadiyya existed 'outside Islam' is more clearly stated. The emphasis of this position is evidenced by the use of the words "exists". Its inclusion indicates that from 1980 to 2005, Ahmadiyya was still considered to endorse various kinds of movements, teachings and dakwah. Therefore it is necessary to emphasize more strongly the existence of the Ahmadiyya outside of Islam.

The 1980 fatwa of MUI on Ahmadiyya states: "For those who have already joined the congregation of Ahmadiyah Qadiyah must immediately return to the true teachings of Islam." Whereas the 2005 fatwa states: "For those who have already joined the Ahmadiyya sect to immediately return to the teachings of the haq Islam (rujü' ila al-haqq), which is in line with the Quran and Al-Hadith." In the 1980 fatwa, the phrase used was 'Jemaah Ahmadiyya' which linguistically refers to a congregation or congregation. The 2005 fatwa used the phrase 'Ahmadiyya sect' which in language refers to a pattern of thought. This indicates a shift in the viewpoint of the Indonesian Ulama Assembly: from the 'congregation', which refers to a group that is more of an ideology or movement, to the Ahmadiyya. Besides that, the estuary that was used as the destination in the call to return was further clarified in the 2005 fatwa, which was to return to the right path of Islam in line with the Qur'an and Hadith.

In relation to the government, the 1980 fatwa of MUI on the Ahmadiyya stated: "In dealing with Ahmadiyah issues, the Indonesian Ulama Council should always be in contact with the Government". In contrast, the 2005 fatwa stated: "The government is obliged to probibit the spread of Ahmadiyah ideas throughout Indonesia and dissolve the organization and close all places of activity" (in bold print on the entry obliged and prohibited). This shows a very significant change. Namely, if in the 1980 fatwa the sentence was in the form of recommendations, 
then in the 2005 fatwa the sentence used was an imperative or an order to the government to ban the spread of Ahmadiyya ideology.

Second, the use of the term "misguided and misleading" should be noted. This term is included in the two fatwas, and is translated from a phrase that is very popular in books relating to the creed and the science of kaläm, namely the term dâllun mudillun. This term seems to be taken and translated in that manner. Of course the use of the phrase "misguided and misleading" emphasizes that the Ahmadiyya sect is heretical and is also active in carrying out acts that are referred to as misleading activities. The term "misguided and misleading" suggests that the Ahmadiyya congregation carried out a series of active propaganda to attract the masses to enter into the flow. The label implies that the flow is not only misguided, but also misleading. Even though it is important to dig deeper, the fact is that the Ahmadiyya congregation is active in preaching and recruiting new members, which in the language of the MUI fatwa is called 'misleading activities'.

Third, the 2005 MUI fatwa regarding Ahmadiyya includes a statement that all Muslims who become Ahmadis are apostates. This sentence is a reassertion of the earlier statement that Aliran Abmadiyah berada di luar Islam' (Ahmadiyya teachings are located outside of Islam). As a logical consequence of Ahmadiyya being declared deviant by MUI, its members and congregation are viewed as apostates. The statement that Muslims who become Ahmadis are apostates, thus, serves to reinforce the earlier statement's implication that Muslims who begin following Ahmadi teachings are apostates who have left Islam.

What is also interesting in the 2005 MUI fatwa is the declaration that: "Pemerintah berkewajiban untuk melarang penyebaran faham Ahmadiyya di seluruh Indonesia dan membekukan organisasi serta menutup semua tempat kegiatannya" (The government is compelled to forbid the spread of Ahmadi teachings in Indonesia, to disband the organization, and to close all its centers of activity). In this statement, two words are bolded: "berkewajiban" (compelled) and "melarang" (forbid). This is certainly intended to provide emphasis, to underscore that the government is compelled to forbid the spread of Ahmadi teachings in Indonesia, to disband the organization, and to close all its centers of activity. However, it is important to note that the bolded words and emphasis are given to the prohibition of the spread of Ahmadiyya teachings. The other two elements of this obligation-if it truly is an 
obligation - are not bolded, and thus not emphasized. As such, from a formalist legal perspective, the main duty of the government is to disband Ahmadiyya as an organization, one registered under Judicial Decree No. JA/RI/23/13 of 13-3-1953 (National Gazette: 31-31953 No. 26). Also interesting is the drastic shift in the organizations identified in these fatwas. The 1980 MUI fatwa specifically identifies the Qadiyan Ahmadiyya; in other words, the Lahore Ahmadiyya are not identified as deviant or outside Islam. MUI held that only the Qadiyan Ahmadiyya recognized another prophet after the Prophet Muhammad SAW, not the Lahore Ahmadiyya. However, the 2005 MUI fatwa no longer includes the word "Qadiyan", meaning that it applies equally to all Ahmadis. According to Assyaukani (2009, 14), this is because in practice it is difficult to differentiate between Qadiyan Ahmadis and Lahore Ahmadis. As such, in the 2005 MUI fatwa, all schools of Ahmadiyya are categorized as being deviant and outside of Islam. If this is true, the 2005 MUI fatwa has a weak foundation. This suggestion is reinforced by the fact that, while MUI consulted nine books on Ahmadiyya in preparing its 1980 fatwa, for its 2005 fatwa MUI did no such thing.

Furthermore, it is important to note that the various forms of persecution and violence experienced may have been influenced by the 2005 MUI fatwa being presented as a legal decision. The 2005 MUI fatwa contains terms such as 'menimbang' (considering), 'mengingat' (recognizing), 'memperhatikan'(noting). This phrasing, which resembles that used in binding legal documents, is not present in the 1980 MUI fatwa. Given the increased discrimination and violence experienced by Ahmadis, it is quite possible that the fatwa's phrasing was quite influential.

\section{Conclusion}

From this study, it may be concluded that, first, the texts of the 1980 and 2005 fatwas regarding Ahmadiyya were significantly different in their form and structure. The 1980 MUI fatwa was more simple and direct, while the 2005 MUI fatwa was more complicated, using legalistic terms such as 'menimbang' (considering), 'mengingat' (recognizing), and 'memperhatikan' (noting). Furthermore, the 1980 MUI fatwa contains a sentence urging the national and provincial MUI branches, as well as the ulamas and dais of Indonesia, to spread word about Ahmadiyya's 
deviance, urging the return of Ahmadis to the path of true Islam, and urging all Muslims to increase their vigilance and avoid being influenced by Ahmadi teachings. In contrast, the 2005 MUI fatwa lacks such a specific dictum, only stating "bagi mereka yang terlanjur mengikuti aliran Ahmadiyah supaya segera kembali kepada ajaran Islam yang haq (rujü' ilá al-haqq) yang sejalan dengan Quran dan Hadits" (That they who have already become followers of Ahmadiyya should return to the true teachings of Islam [rujü'ilá al-haqq] in accordance with the Quran and hadiths). Furthermore, while the 1980 MUI fatwa underscores the importance of MUI working with the government, the 2005 MUI fatwa lacks such a statement.

Second, in terms of the lexicon, both fatwas position Ahmadiyya vis-a-vis Islam. However, differences are evident. The 1980 MUI fatwa uses the phrase "di luar Islam" (outside Islam), while the 2005 MUI fatwa uses the phrase "berada di luar Islam" (located outside Islam). Furthermore, both fatwas use the term sesat menyesatkan (deviant and deviating), a term translated from the Arabic dallun mudillun, common in books on Islamic behavior and beliefs. This phrase is intended to emphasize that Ahmadiyya, aside from being perceived as deviant, is also considered to lead others to deviant behaviors. Furthermore, the 2005 MUI fatwa includes the sentence "orang Islam yang mengikutinya adalah murtad (keluar dari Islam)" (those Muslims following its teachings are apostates), which is not found in the 1980 MUI fatwa. This sentence thus reiterates the implication that Ahmadiyya are outside Islam, providing greater emphasis to the perception that Ahmadis are apostates.

Third, the 2005 MUI fatwa includes two bolded words regarding the government's obligations. These words, "berkewajiban” (compelled) and "melarang" (forbid), emphasize that the main duty of the government is to prohibit the spread of Ahmadi teachings. Fourth, the 1980 MUI fatwa was targeted at Qadiyan Ahmadiyya, while the 2005 MUI fatwa was targeted at all Ahmadis, without specifying Qadiyan or Lahore.

Fifth, the various forms of persecution and violence experienced by Ahmadis may have been influenced in part by the formulation of the 2005 MUI fatwa, which resembled a legal decision. 


\section{Endnotes}

- This paper is part of the author's dissertation at Gadjah Mada University. Thank you to Dr. Amir Ma'ruf as the promoter and Dr. Fadlil Munawwar Manshur as co-promoter. Thank you to colleagues who gave input and criticism in improving this article: Muhammad Ridwan, Sebelas Maret University, Solo and Dr. Suhandano, Gadjah Mada University.

1. The correspondence between Indonesian scholars and Middle Eastern scholars occurred for a long time. One of the works which provides evidence of this correspondence is the book Muhimmat al-nafäis fi bayan asilat al-hadith. This book contains a collection of fatwas from prominent muftis in answering problems raised by Indonesian scholars (Nusantara) at the end of the nineteenth century. Some names in the book that were used as references and were asked to give a fatwa include Muhammad Zaynī Daḥlān (Mufti from the Shafi'i School of 1871), Muhammad Hasaballāh (Mufti from the Syafi'i School. Dead in 1917), 'Abd al-Rahmān ibn 'Abdullāh Sirāj al-Hanafí (Mufti of the Hanafi school of thought. Died 1896), Muḥammad Sa'īd Babalsil (died 1912), and 'Abd al-Qādir ibn 'Abd al-Raḥmān al-Fațānī. For more clearly see the explanation, Niko Kaptein (1995).

\section{Bibliography}

"Ahmadiyah Ada Sejak 1925, Setelah 2008 Diperlakukan Diskriminatif." 2017. Kompas.com. https://nasional.kompas.com/read/2017/10/10/23501161/ ahmadiyah-ada-sejak-1925-setelah-2008-diperlakukan-diskriminatif (May 22, 2018).

"Akibat Fatwa MUI, Ratusan Umat Islam Menderita di Transito." 2015. Madina Online. http://www.madinaonline.id/sosok/wawancara/akibat-fatwa-mui-ratusan-umatislam-menderita-di-transito/ (May 13, 2018).

Assyaukanie, Luthfi. 2009. "Fatwa and Violence in Indonesia." Journal of Religion and Society 2(1): 1-21.

Bisri, A. Mustofa. 2010. Koridor: Renungan A. Mustofa Bisri. Jakarta: Penerbit Buku Kompas.

2016. "Fatwa dan Fatwa." www.jpnn.com. https://www.jpnn.com/news/ fatwa-dan-fatwa.

"Cak Nun: Fatwa MUI Tak Mengikat." http://www.watchindonesia.org/7290/ baru-merdeka-20-persen?lang=ID (May 13, 2018).

Darmadi, Dadi. 2016. "The Meccan Fatwas and the Globalized Discourse of Exclusion: The Case of Anti-Ahmadiyah Movements In Indonesia." Heritage of Nusantara: International Journal of Religious Literature and Heritage (e-Journal) 2(1): $22-50$.

Dijk, Teun van. 2000. Ideology and Discoursce: A Multidiciplinary Introduction. Barcelona: Universitat Oberta de Catalunya.

Djajasudarma, F. 2009. Semantik: Pemahaman Ilmu Makna. Bandung: Refika Aditama. 
Foley, William A. 2001. Anthropological Linguistics: An Introduction. Oxford: Blackwell.

Fuller, Andy. 2011. "Religious Freedom In Indonesia: Curious Cases of Dialogues, Fatwa's and Laws." Journal of Indonesian Islam 5(1): 1-16-16.

Hallaq, Wael B. 1984. "Was the Gate of Ijtihad Closed?" International Journal of Middle East Studies 16(1): 3-41.

Halliday, Michael Alexander Kirkwood. 1978. Language as Social Semiotic: The Social Interpretation of Language and Meaning. Edward Arnold.

Hamdi, Ahmad Zainul. 2007. "Radikalisasi Islam Melalui Institusi Semi-Negara: Studi Kasus Atas Peran MUI Pasca-Soeharto.” Istiqro' 6(1).

Hasyim, Syafiq. 2015. "Fatwa Aliran Sesat dan Politik Hukum Majelis Ulama Indonesia (MUI)." Al-Ahkam 25(2): 241-66.

. 2016. "The Council of Indonesian Ulama (MUI) and Aqida-Based Intolerance: A Critical Analysis of Its Fatwa on Ahamdiyah and Sipilis.” In Religion, Law and Intolerance in Indonesia, eds. Tim Lindsey and Helen Pausacker. London: Routledge.

Hooker, M.B. 1997. "Islam and Medical Science: Evidence from Malaysia and Indonesian Fatawa 1960-1995.” Studia Islamika 4(3): 1-31. DOI: 10.15408/ sdi.v4i4.764.

- 2003. Indonesian Islam Social Change Through Contemporary Fatawa. Honolulu: Anlen and Unwin.

Hosen, Nadirsyah. 2004. "Behind The Scenes: Fatwa Majelis Ulama Indonesia (1975-1998)." Journal of Islamic Studies 15(2): 147-79.

Imron, D. Zawawi. 2012. “Teks Pidato Kebudayaan D. Zawawi Imron.” https:// www.nu.or.id/post/read/37200/teks-pidato-kebudayaan-d-zawawi-imron.

Al-Jauzi, Ibnu Qayyim. 2007. I'lamul Mauqi'in. Beirut: Darul Kutub.

Jum'ah, Ali. 2008. Shinaatul Ifta. Alexandria: Syiarkah Nahdlah Misr.

Kaptein, Nico. 1995. "Meccan Fatwas from the End of the Nineteenth Century on Indonesian Affairs.” Studia Islamika 2(4). DOI: 10.15408/sdi.v2i4.824.

Koerner, Catherine, and Widodo Dwi Putro. 2017. “The Socio-Legal Construction of Ahmadiyah as a Religious Minority by Local and National Government Policy: Restrictions before the Law, a Challenge for Religious Freedom in NTB, Indonesia." International Journal of Indonesian Studies 4(1): 14-30.

Lukmana, Iwa. 2003. "Critical Discoursce Analysis: Rekonstruksi Kritis Terhadap Makna." Jurnal Pandidikan Bahasa, Sastra dan Pengajarannya.

Majelis Ulama Indonesia. 2005a. 20 Tahun Majelis Ulama Indonesia. Jakarta: Sekretariat MUI. 
- 2005b. Hasil Fatwa Munas VII Majelis Ulama Indonesia. Jakarta: Sekretariat MUI.

Mariani, Nina. 2013. "Ahmadiyah, Conflicts, and Violence in Contemporary Indonesia." Indonesian Journal of Islam and Muslim Societies 3(1): 1-30.

Mudzhar, M. Atho. 1993. Fatwas of the Council of Indonesian Ulama: A Study of Islamic Legal Thought in Indonesia, 1975-1988. Jakarta: INIS.

Pamungkas, Cahyo, ed. 2017. Mereka yang Terusir: Studi tentang Ketahanan Sosial Pengungsi Ahmadiyah dan Syiah di Indonesia. Jakarta: Yayasan Pustaka Obor Indonesia.

“Penyegelan Masjid Ahmadiyah Depok - Infografik Tirto.id.” tirto.id. https:// tirto.id/penyegelan-masjid-jemaah-ahmadiyah-depok-cp4y.

“Sejarah MUI.” https://mui.or.id/sejarah-mui (June 27, 2018).

Sholeh, Asrorun Niam. 2016. Metodologi Penetapan Fatwa Majelis Ulama Indonesia. Jakarta: Erlangga.

Smith, Linda Tuwihai. 2012. Decolonizing Methodologies: Research and Indegenous Peoples. New York: Zed Books Ltd.

Sobary, Mohamad. 2010. NU dan Keindonesiaan. Jakarta: Gramedia Pustaka Utama.

Suhandano. 2004. "Klasifikasi Tumbuh-Tumbuhan dalam Bahasa Jawa: Sebuah Kajian Linguistik Antropologis." Ph.D. Dissertation. Universitas Gadjah Mada.

Suryana, A'an. 2017. "Discrepancy in State Practices: The Cases of Violence against Ahmadiyah and Shi'a Minority Communities during the Presidency of Susilo Bambang Yudhoyono." Al-Jamiah: Journal of Islamic Studies 55(1): 71-104.

Tigor, Bonar, Halili, and Sudarto. 2017. Kondisi Kebebasan Beragama Di Indonesia 2016. Setara Institute.

“Wapres Minta Fatwa MUI Tak Jadi Ketakutan Baru.” detiknews. https://news. detik.com/berita/d-1073810/wapres-minta-fatwa-mui-tak-jadi-ketakutanbaru.

Wilson, Chris. 2018. "Ethnic, Religious, And Regional Conflict." In Routledge Handbook of Contemporary Indonesia, London \& New York: Routledge.

Al-Zabidi, Muhammad Murtada. 1965. Taj Al-Arus min Jawahir al-Qamus. Kuwait: Matba'ah Hukumah Kuwait.

Fariz Alnizar, Universitas Nabdlatul Ulama Indonesia, Indonesia. Email: fariz@unusia.ac.id. 


\section{Guidelines}

\section{Submission of Articles}

tudia Islamika, published three times a year since 1994, is a bilingual (English and Arabic), peer-reviewed journal, and specializes in Indonesian Islamic studies in particular and Southeast Asian Islamic studies in general. The aim is to provide readers with a better understanding of Indonesia and Southeast Asia's Muslim history and present developments through the publication of articles, research reports, and book reviews.

The journal invites scholars and experts working in all disciplines in the humanities and social sciences pertaining to Islam or Muslim societies. Articles should be original, research-based, unpublished and not under review for possible publication in other journals. All submitted papers are subject to review of the editors, editorial board, and blind reviewers. Submissions that violate our guidelines on formatting or length will be rejected without review.

Articles should be written in American English between approximately 10.000-15.000 words including text, all tables and figures, notes, references, and appendices intended for publication. All submission must include 150 words abstract and 5 keywords. Quotations, passages, and words in local or foreign languages should 
be translated into English. Studia Islamika accepts only electronic submissions. All manuscripts should be sent in Ms. Word to: http:// journal.uinjkt.ac.id/index.php/studia-islamika.

All notes must appear in the text as citations. A citation usually requires only the last name of the author(s), year of publication, and (sometimes) page numbers. For example: (Hefner 2009a, 45; Geertz 1966, 114). Explanatory footnotes may be included but should not be used for simple citations. All works cited must appear in the reference list at the end of the article. In matter of bibliographical style, Studia Islamika follows the American Political Science Association (APSA) manual style, such as below:

1. Hefner, Robert. 2009a. "Introduction: The Political Cultures of Islamic Education in Southeast Asia," in Making Modern Muslims: The Politics of Islamic Education in Southeast Asia, ed. Robert Hefner, Honolulu: University of Hawai'i Press.

2. Booth, Anne. 1988. "Living Standards and the Distribution of Income in Colonial Indonesia: A Review of the Evidence." Journal of Southeast Asian Studies 19(2): 310-34.

3. Feener, Michael R., and Mark E. Cammack, eds. 2007. Islamic Law in Contemporary Indonesia: Ideas and Institutions. Cambridge: Islamic Legal Studies Program.

4. Wahid, Din. 2014. Nurturing Salafi Manhaj: A Study of Salafi Pesantrens in Contemporary Indonesia. PhD dissertation. Utrecht University.

5. Utriza, Ayang. 2008. "Mencari Model Kerukunan Antaragama." Kompas. March 19: 59.

6. Ms. Undhang-Undhang Banten, L.Or.5598, Leiden University.

7. Interview with K.H. Sahal Mahfudz, Kajen, Pati, June $11^{\text {th }}$, 2007.

Arabic romanization should be written as follows:

Letters: ', $b, t, t h, j, h, k h, d, d h, r, z, s, s h, s, d, t, z, ', g h, f, q, l$, $m, n, h, w, y$. Short vowels: $a, i, u$. long vowels: $\bar{a}, \overline{\mathrm{i}}, \overline{\mathrm{u}}$. Diphthongs: $a w$, ay. Tà marbūtāa: t. Article: al-. For detail information on Arabic Romanization, please refer the transliteration system of the Library of Congress (LC) Guidelines. 
ستوديا إسلاميكا (ISSN 0215-0492; E-ISSN: 2355-6145) مجلة علمية دولية محكمة تصدر عن مركز دراسات الإسلام والمجتمع (PPIM) بجامعة شريف هداية الله الإسلامية الحكومية بجاكرتا، تعنى بدراسة الإسلام في إندونيسيا خاصة وفي جنوب شرقي آسيا عامة. وتستهدف المجلة نشر البحوث العلمية الأصيلة والقضايا المعاصرة حول الموضوع، كما ترحب بإسهامات الباحثين أصحاب التخصصات ذات الصلة. وتخضع جميع الأبحاث المقدمة للمجلة للتحكيم من قبل لجنة مختصة.

تم اعتماد ستوديا إسلاميكا من قبل وزارة البحوث والتكنولوجيا والتعليم العالي بجمهورية إندونيسيا باعتبارها دورية علمية (رقم القرار: 32a/E/KPT/2017).

ستوديا إسلاميكا عضو في CrossRef (الإحالات الثابتة في الأدبيات الأكاديمية) منذ ع ا • ب، وبالتالي فإن جميع المقالات التي نشرتا مرقمة حسب معرّف الوثيقة الرقمية (DOI). ستوديا إسلاميكا بجلة مفهرسة في سكوبس (Scopus) منذ .ب مايو 0 . ب.

$$
\begin{aligned}
& \text { قيمة الاشتر الك السنوي خارج إندونيسيا: }
\end{aligned}
$$

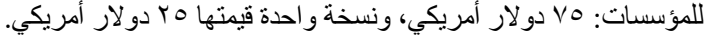

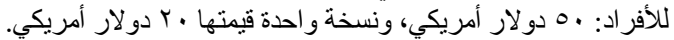

$$
\begin{aligned}
& \text { والقيمة لا تشمل نفقة الإرسال بالبريد الجوي. ونسي. }
\end{aligned}
$$

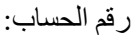

$$
\begin{aligned}
& \text { خارج إندونيسيا (دولار أمريكي): ابن }
\end{aligned}
$$

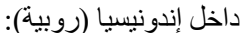

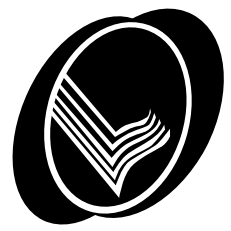




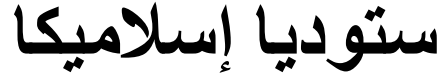 \\ مجلة إندونيسيا للار اسات الإسلامية}

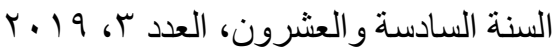

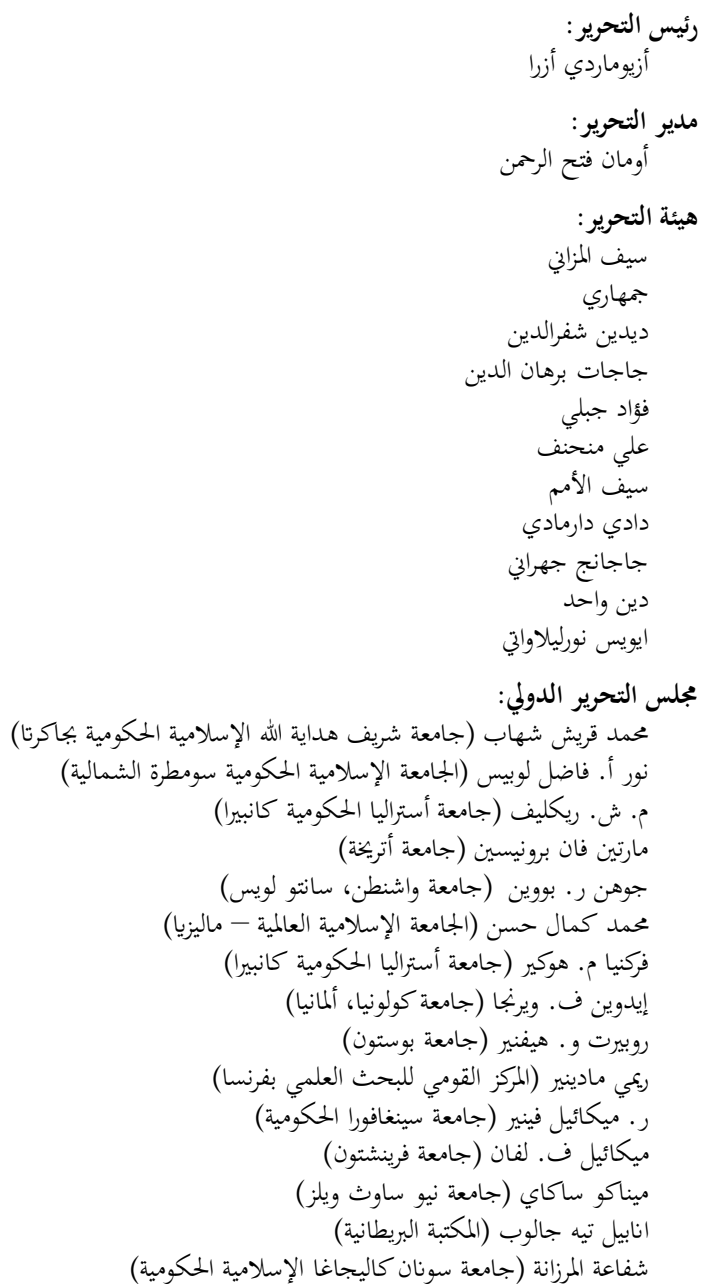

مساعد هيئة التحرير:

تيستريونو

محمد نداء فضلان

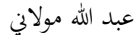

مراجعة اللغة الإنجليزية:

بنيمن ج. فريمان

دانيل فتريون

موسى بتول

مراجعة اللغة العربية:

توباغوس أدي أسناوي

تصميم الغلاف:

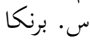





\section{لالتوايا السال|مسيا}




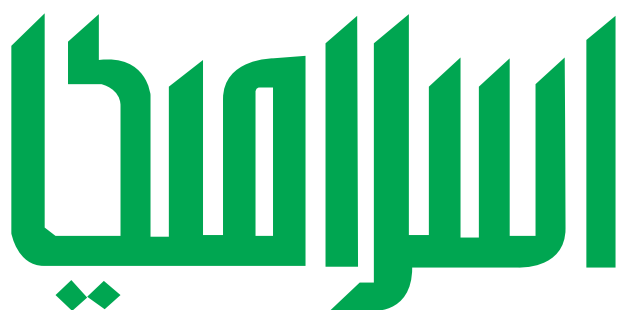

السنة السادسة والعشرون، العدد ب، 9 1 بـ

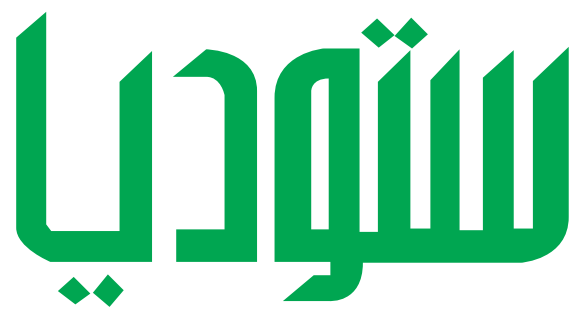

بجلة إنلدونيسية للدراسات الإسلامية

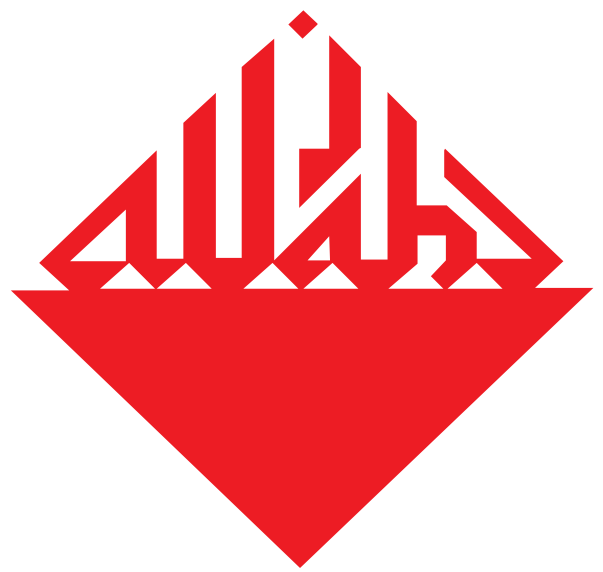

الشبكائ الاجتماعية والمنحرية

Sumatera y Lombok بيلن هسلمين

كاسة كيم تهنة وهنطوط Sasak جمال الدين 